\title{
MYELOMATOSIS PRESENTING WITH ACUTE INTESTINAL OBSTRUCTION
}

\author{
J. M. Abouna, B.Sc., M.B., B.S.(Durh.) \\ House Surgeon, Department of Surgery, Royal Victoria Infirmary, Newcastle upon Tyne
}

\begin{abstract}
Ever since Kahler described myelomatosis in 1889 , some 44 years after the discovery by Dr. Bence Jones of the abnormal proteinuria frequently seen in this condition, many cases have now been reported in which this disease has first presented with an unusual clinical picture.

Although gastro-intestinal discomfort, nausea, vomiting and melæna have been seen in cases of myelomatosis, frank intestinal obstruction, as the only clinical manifestation of this disease, does not appear to have been reported in the English medical literature.
\end{abstract}

\section{Case History}

A retired miner aged 75 was admitted to hospital as an emergency, complaining of abdominal pain and distension of three days' duration. For several days before admission, the patient had felt unwell with anorexia, abdominal discomfort, dyspnoea and persistent productive cough. Three days before admission, he was suddenly seized with a severe, colicky abdominal pain. Twenty-four hours later, the pain began to subside but abdominal distension and repeated vomiting became prominent symptoms. There was no evidence of blood or fæculent material in the vomit. The bowel had not been evacuated for five days, although flatus had been passed. At no time had there been any hæmaturia or gastrointestinal bleeding and there was no history of loss of weight.

Twelve years previously he was found to have pernicious anæmia and this had been adequately controlled with regular injections of Cytamen. Appendicectomy had been performed 50 years previously.

Examination revealed an ill and dehydrated patient with a temperature of $98.4^{\circ} \mathrm{F}$. and a thready pulse of $120 / \mathrm{min}$. The blood pressure was $140 / 80 \mathrm{~mm}$. $\mathrm{Hg}$. There was dullness and impaired air entry in the right lung base. The abdomen was grossly distended but there was no visible peristalsis. Slight, generalized tenderness was elicited but rigidity was absent. Bowel sounds were somewhat exaggerated and hernial sites were intact. Rectal examination was negative.

\section{Investigations}

Flat X-ray of the abdomen showed marked distension of small and large bowel with fluid levels. (Fig. I) $\mathrm{X}$-ray of the chest confirmed consolidation in the right base. The hæmoglobin was $80 \%$ (12.5 g.). The blood urea was $77 \mathrm{mg}$./ $100 \mathrm{ml}$.; serum electrolytes were within normal limits. The urine S.G. was 1020 and it contained no abnormal constituents. Facal occult blood examination was negative.

A clinical diagnosis of acute intestinal obstruction was made and a laparotomy was performed approximately

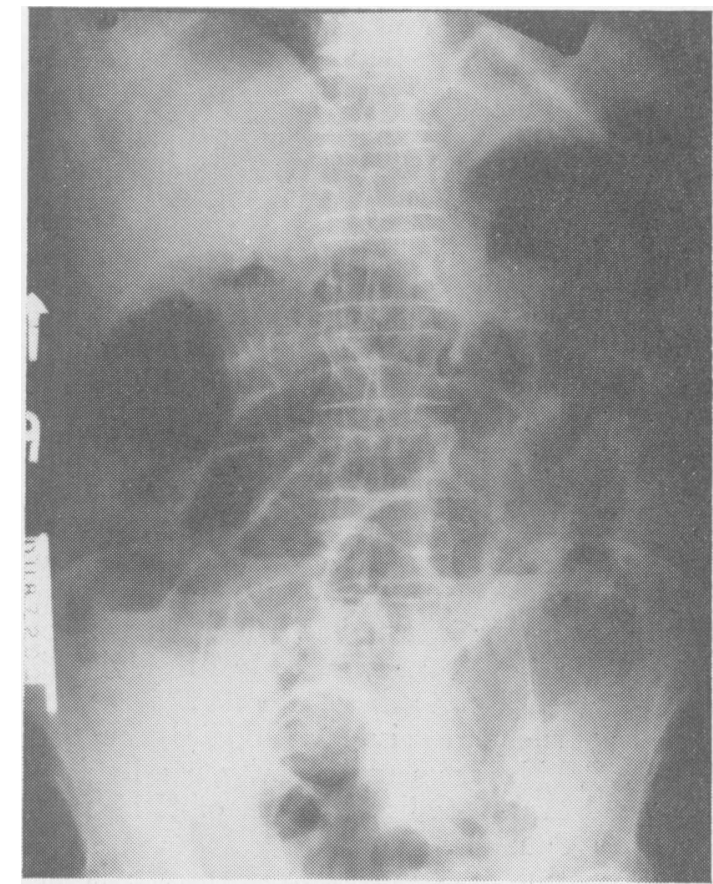

FIG. 1.-Radiograph of abdomen showing distension of bowel with fluid levels.

four hours after admission. At operation (Mr. F. C. Walker) there was gross dilatation of small and large bowel down to the sigmoid colon with considerable œedema of the bowel wall. Many segments showed evidence of recent subserous hæmorrhages. There was no evidence of mechanical obstruction or mesenteric vascular occlusion. Intestinal decompression was then performed by needle aspiration as originally described by Lowdon (I95I) and the abdominal wall was closed in layers.

\section{Post-operative Progress}

On the following day the temperature rose to ror $\mathrm{F}$. and signs of left lobar pneumonia appeared. 'This responded well to chemotherapy. Two days later spontaneous evacuation of the bowel recurred but the abdominal distension persisted.

In view of this and of the unusual operative findings further investigations were performed: 


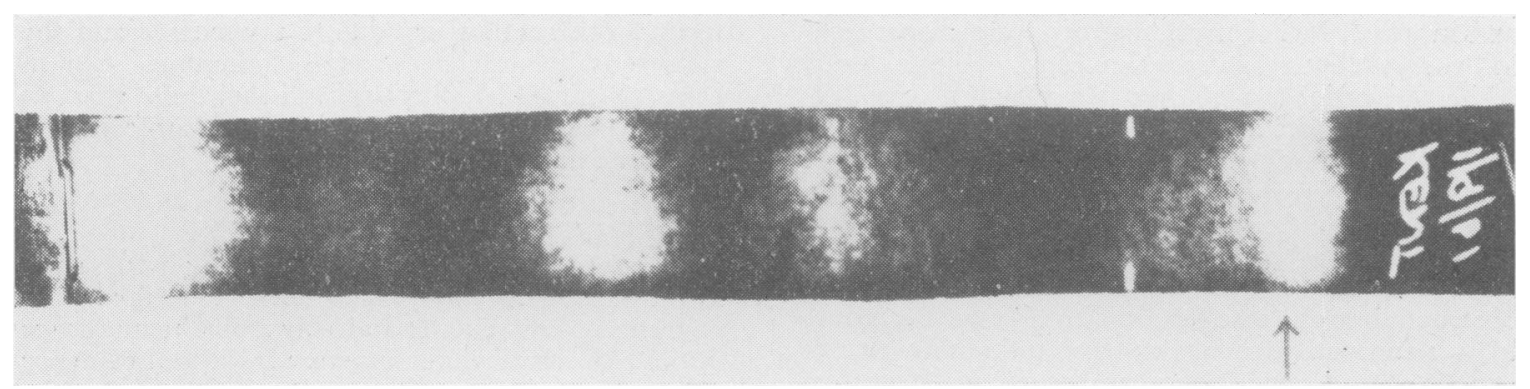

FIG. 2.-Protein electrophoresis showing marke $\mathbb{1}$ increase in gamma globulins confirmed to an isolated band. ( $\uparrow)$

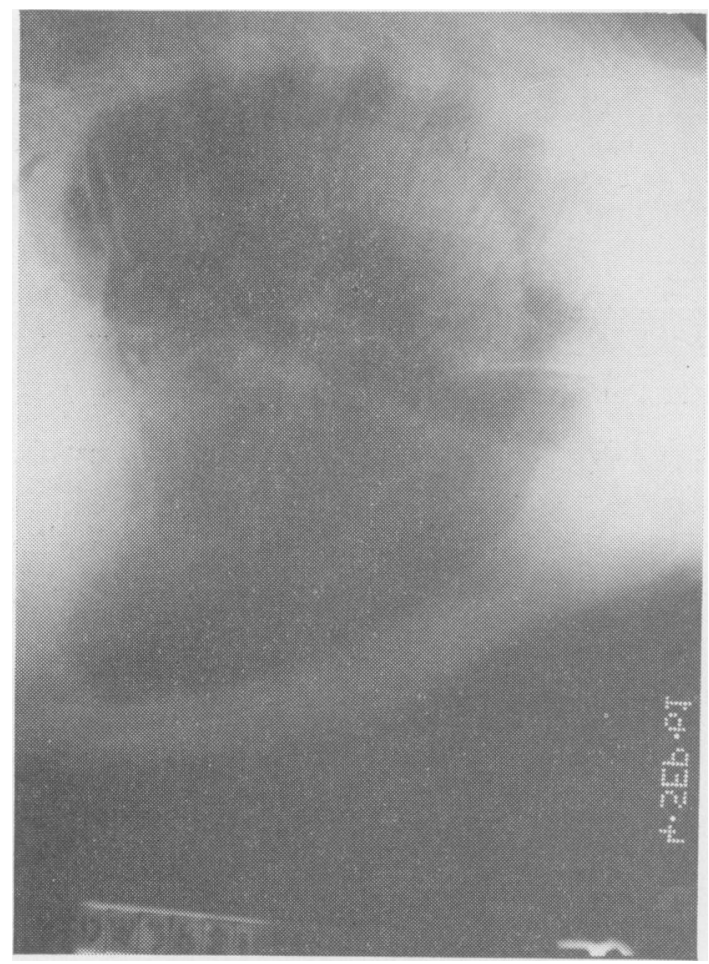

FIG. 3.-Radiograph of dorsal spine showing collapse of the body of the seventh vertebra.

Blood examination revealed a hypochromic anæmia with normal total and differential white cell count; platelets 500,000 per cubic mm.; reticulocytes $2.8 \%$. The ESR was $82 \mathrm{~mm}$./ hr.; clotting time five minutes and bleeding time seven minutes; serum bilirubin was $0.2 \mathrm{mg} . / 100 \mathrm{ml}$; f flocculation and turbidity tests were slightly abnormal, the serum alkaline phosphatase was 7 K.A. units. The total serum proteins, 6.9 g./100 ml., albumin $3 \mathrm{~g}$. and globulin $3.9 \mathrm{~g}$.

In view of the clinical picture, the abnormal liver functions, the raised ESR, and the alteration in serum proteins, a collagen vascular disease and carcinomatosis were suspected.

Protein electrophoresis was performed and this showed a marked increase in the gamma globulins

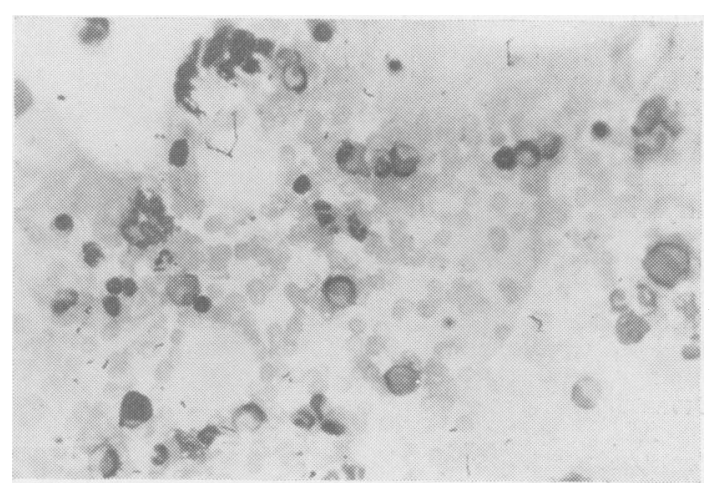

FIG. 4.- Sternal marrow biopsy showing excess of primitive plasma cells. $(\times 260)$

confined to an isolated band, suggesting myelomatosis (Fig. 2). Skeletal X-rays showed collapse of the body of the seventh dorsal vertebra (Fig. 3). Examination of the sternal marrow (Dr. R. B. Thompson) showed an excess of plasma cells, many being primitive and binucleate, confirming an early myelomatosis (Fig. 4).

During the remainder of the post-operative period, bowel functions returned to a satisfactory rhythm, although abdominal distension subsided only a little. In view of the patient's age and the absence of symptoms no specific treatment was undertaken meantime and he was discharged on the 14 th post-operative day.

\section{Discussion}

Myelomatosis has been classified by several authors into solitary myeloma, multiple myeloma and extra-medullary plasmacytoma (Osserman, r959; Innes and Newell, r 96I; Martin, I96I).

Annamanthodo and Robertson (1959) and Sharmer and Shrivastav (I96I) described cases of extra-medullary plasmacytoma affecting the gastrointestinal tract and on reviewing the literature, it was found that 27 such cases have now been reported in the world's medical literature. Three of these cases had presented with symptoms of acute intestinal obstruction due to the presence of a tumour, but in none of them were there any of the clinical and biochemical features of multiple myeloma. However, Hefferman (1947) described a case of intestinal obstruction due to the presence of plasmacytoma in the duodenum and the pancreas 
and in which foci of myelomatosis were discovered in the skeleton at post-mortem examination; while Divertie (1959) has described a case of œsophageal obstruction due to amyloid deposits complicating multiple myeloma.

Although peripheral neuropathy, as a complication of myelomatosis, has been described (Hassan and Yousef, 1959; Barron, Roland and Zimmerman, 1960), it is improbable that the intestinal obstruction in the case reported could have been due to a neuropathy involving the autonomic nerve supply of the bowel, because the clinical features of the obstruction were not those of a paralytic ileus.

The information available from the study of this case is not sufficient to enable one to put forward a convincing explanation for the obstruction. It is reasonable to suppose, however, that the presence of myelomatosis was somehow related to the pathogenesis of this obstruction. Although there was no evidence of an extra-medullary plasmacytoma, nor was there any macroscopic evidence of amyloid infiltration, it is conceivable that the in- testinal obstruction was due to the œdema and the subserous hæmorrhages, as is sometimes seen in cases of Henoch's purpura, and that these changes in the bowel wall were unknown manifestations of diffuse myelomatosis.

\section{Summary}

A case of myelomatosis, presenting with acute intestinal obstruction, has been described. At operation, only œdema and subserous hæmorrhage in the bowel wall were discovered, without evidence of mechanical obstruction. It appears from the literature, that all cases of myeloma presenting with intestinal obstruction previously reported were due to the presence of plasmacytoma in the bowel. The pathogenesis of the obstruction is discussed.

I am grateful to Professor A. G. R. Lowdon for permission to publish this case, and wish to thank Mr. F. C. Walker for his encouragement and Dr. E. A. Cameron for his guidance. I am indebted to Dr. R. B. Thompson for kindly examining the bone marrow.

\title{
REFERENCES
}

Annamunthodo, H., and Robertson, W. (1959): Primary Myeloma of the Stomach, Brit. F. Surg., 449.

Barron, K., Roland, L., and Zimmerman (1 960): Neuropathy with Malignant Tumour Metastases, f. nerv. ment. Dis., I3I, 10.

DiverTIE, M. (1959): Esophageal Obstruction due to Amyloid Deposits Complicating Multiple Myeloma, Proc. Mayo Clin., 34, 529.

DanCASTER, C. P., Hussein, O. A., and JACKson, W. (1959): Clinical Manifestations of Multiple Myelomatosis, Postgrad med. $\mathcal{F}$., 35, 662.

Hampton, J., and GrandY, J. (1957): Multiple Myeloma of the Gastro-intestinal Tract, Ann. Surg., 145, 415.

Hassan, A. H., and Yousef, A. (1959): Neurological Complications of Multiple Myelomatosis, 手. Egypt. med. Ass., 42, 386.

HefFerman, A. (1947): Plasmacytoma of Pancreas and Duodenum causing Acute Intestinal Obstruction, Lancet, i, 910.

INNES, J., and Newall, J. (196I): Myelomatosis, Ibid., i, 239.

LowDon, A. G. R. (195I): Deflation of Distended Bowel at Operation, Ibid., i, I I03.

MARTIN, N. A. (196r): The Incidence of Myelomatosis, Ibid., i, 237.

Osserman, E. F. (1959): Plasma Cell Myeloma-Clinical Aspects, New Engl. med. F., 261, 952.

Sharmer, K. D., Shrivastav, J. D. (I96r): Extra-Medullary Plasmacytoma of Gastro-intestinal Tract and Review of the Literature, Arch. Path. (Chicago), 7r, 229.

SNAPPER, I., Turner, L., and Moscovitz, H. (1953): Multiple Myeloma. New York: Grune and Stratton.

\section{JUGULAR PHLEBECTASIA}

\author{
E. Leighton John, M.B., B.S., F.R.C.S.(Edin.) \\ Neath General Hospital, Glamorganshire
}

JUGULAR phlebectasia is a rare anomaly of the neck reins and is of interest and importance in the differential diagnosis of swellings in the neck. Very few cases are reported in the literature, and the following case occurred in a young child.

\section{Case Report}

A 7-year-old girl was seen in January, $196 \mathrm{r}$, regarding a swelling in the neck which had been noticed intermittently since birth. The story was a curious one, in that the swelling varied in size at different times, and apparently became most prominent when the child was emotionally upset, while at other times it was not visible. There were no previous ailments.

On Examination. A soft swelling, fluctuant in character, was visible and palpable on the right side of the neck below the angle of the jaw, and over the upper third of the sternomastoid muscle. The swelling was smooth and rounded and approximately $5.0 \mathrm{~cm}$. $\times 3.5$ $\mathrm{cm}$. in size.

It was noticed to vary in size during the examination and at times disappeared completely (Fig. I). Direct pressure could empty the swelling completely and it would reappear slowly.

It was also observed that the swelling enlarged 